\title{
All the Rage: Digital Bodies and Deadly Play in the Age of the Sucide Bomber
}

\author{
Carolyn Guertin
}

\section{Violence is Viral}

"Violence is viral..." Jean Baudrillard says in The Spirit of Terrorism, "it operates by contagion, by chain reaction, and it gradually destroys all our immunities and our powers to resist" (94). Seung-Hui Cho succumbed to those powers at Virginia Tech, as did Kimveer Gill at Dawson College in Montreal, and Eric Harris and Dylan Klebold at Columbine, and too, too many others to mention. Meanwhile, half the world away, young men and women in the grip of a spiritual agenda enact similar acts of suicidal revenge to answer their own need for salvation, a sense of entitlement, and a retaliatory yearning to set right real or imagined wrongs. As much as these killers' acts are incomprehensible, they are simultaneously sanctioned by our own news media and entertainment industry. If these lost souls do not know where to draw the line, it is surely because our culture makes no distinction. In fact, the infamous psychedelia professor Timothy Leary, who performed his own death as a fashion statement and online signature media event in "designed dying," said "The most important thing you can do in your life is to die." We are immersed in visual violence of all kinds on a daily basis as entertainment. Suicide, especially murder-suicide, has become commonplace, yes, but more to the point it is now both fashionable and newsworthy. We are bombarded by popular culture forms that require ever worse- bigger and more dramatic events—-to feed its massive hunger. These symbolic acts (and to say they are symbolic is not to suggest that they do not cause very real carnage) of blowing up bridges and markets in Baghdad, twin towers in Manhattan, or performing enactments of resentment against those Cho claimed had trust funds and drank cognac are happenings made real and more powerful because of their dramatization as carefully staged events for the media.

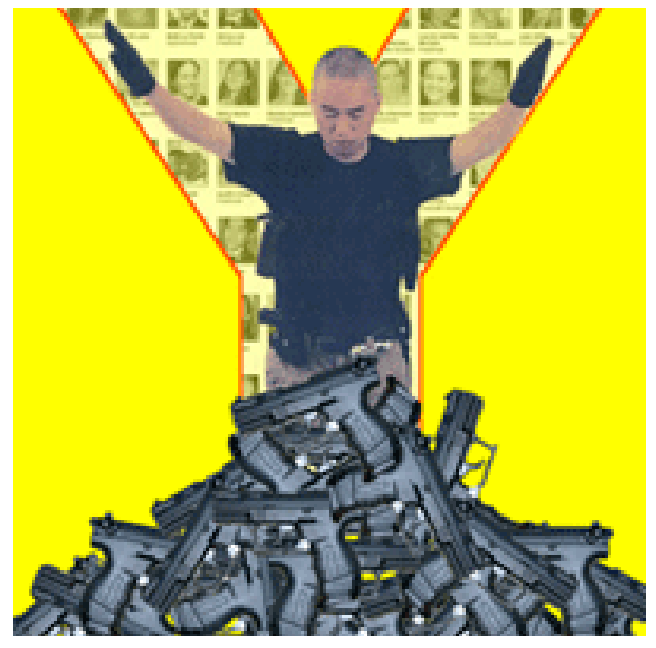

Copyright Stephanie Tripp, 2007. 
Serial killers, mass murderers and suicide bombers appropriate the tools of the powerful (from planes to cameras to the World Wide Web) to spread terror far more effectually than their considerable death counts do, for the fear they cause is a viral weapon that spreads like a pandemic via our own addiction to networked communication. In "Packaging the Suicide Bomber," Hal Niedzviecki notes that "the attraction of becoming a suicide bomber is not the fantasy of being rewarded with virgins in heaven, but the intense feeling of being noticed in a world where being noticed-preferably on video-has somehow become the sole crowning achievement in and of itself" (68; qtd in Murray 2005). Murder-suicide is the quickest road to celebrity, and the latest incarnation of Andy Warhol's 15 minutes of fame.

The special, grizzly weapon that the suicide bomber has that increases his terror quotient above the others is his body. In the essay "Thanatopolitics: On the Use of Death for Mobilizing Political Life," Stuart Murray calls this phenomenon "biopolitics" where the body of the terrorist actually becomes a weapon of destruction, where his shattered body parts become destructive projectiles, just like the ensuing broadcast images of the violent event do. Murray (2006) observes that "The attacker's body is literally weaponized. Shards of bone become human shrapnel" (p. 207). Similarly, in "McLuhan, Rhetoric, Politics," Murray says, the media guru Marshall:

McLuhan warns us that "every separatist group of the future will have an educated—and therefore skilled-terrorist fringe" (Globe Village 115). With uncanny premonition, he prophesied that "The satellite will distribute terrorist paranoia around the world in living color to match each accelerating disruptive event" (ibid) (Murray 2005).

McLuhan saw the media as extensions of our bodies. Media act in effect as networked, externalized nervous systems. This phenonmenon is equal parts symptom and manifestation of McLuhan's prophetic vision of a global village: the violent, conflict-ridden, media-saturated world that is the 21st century. Media ecologist Lance Strate observes that, as McLuhan clearly saw in Understanding Media, "Guns and cameras are both media of communication" with guns acting as extensions of the "fist and fingernail" and cameras as instruments of voyeuristic violence (Strate):

Guns and cameras are both methods by which people communicate, sending messages to their target, and to bystanders alike... Guns and cameras are both weapons, both used to attack and cause harm... both used to control and imprison-that is why we talk about cameras using words like shoot, snapshot, load (the film), capture (the subject, the moment), that isthis is a deep metaphor that reveals an often-unconscious understanding of the link between the two technologies.

We can therefore understand that the video and stills prepared by the Virginia Tech killer, and sent to NBC, was an assault by other means, another violent act prepared and perpetrated by a mass murderer. The intent, clearly, was not only to justify his actions, but to incite more violence by others. The model that he was imitating was not so much fiction films, as some commentators have suggested, but the video recordings made by suicide bombers coming out of the Arab world... (Strate).

We see these parallels at suicide bombers recruitment sites and in the executions of prisoners broadcast by Iraqis over the Web. The roles such images play in our culture are highly ambiguous. As terrorism spreads messages of fear, we simultaneously revel in their instantaneous global broadcast and are appalled by their content. In reality these attacks come from the inside out for they mirror Western culture's violence as they incite and recruit us to do more harm against each other and ourselves.

\section{Seeds of Terrorism}

Jean Baudrillard argues that the seeds of terrorism were planted with the collapse of Soviet Communism, and that, previously, that balanced symmetry of two global powers had kept the forces for good and the forces for evil at a standoff. As the military might of the United States has grown ever more powerful in the interim since that collapse, there has come to be no possible military challengers, and so the only remaining forms of attack against the most powerful nation in the world (for the most powerful always must have challengers) can be symbolic attacks through guerrilla methods.

While all major religions condemn suicide, acts of violence on the enemies of Islam have come to be seen as acceptable means of performing extreme religious devotion, secular desires for revenge, and acts of cruelty. Encouraged by unscrupulous recruiters in person, in the media and at special Websites, suicide bombers aim for critical mass in human casualties and media spectacle. Campus killers similarly derive their power from delusions of grandeur and an obsession for celebrity among the ranks of this dubious genealogy. Cho aligned himself with 
Christ and his suffering, and Gill saw himself as the Angel of Death. It is the media that render these brief reigns of terror as a performance to be consumed and it is us who cannot look away. Saddam Hussein was similarly and pornographically paraded before us first as a docile medical prisoner subject to dissection, (revisit the images at the BBC's site) and then as a subject of raw documentary footage, simultaneously real and unbelievable, with his final moments performed and "filtered through cellphones and YouTube, passing through Sky News and CNN and Al Jazeera" for our viewing pleasure (Burgess). (Time magazine's coverage of the event, for instance, can be seen here).

The danger of the media, Baudrillard warns in Spirit of Terrorism, is that the "image consumes the event," that is, absorbs it and gives it back as an object of consumption (Baudrillard 27). NBC got considerably richer by showing Cho's images, and show them he knew they would when he mailed them his terrible "multimedia manifesto" between attacks. Then, predictably, twelve hours later NBC expressed crocodile tears of remorse, saying in future they would "strictly limit" their use of these images—not, you will notice, cease using them (Mikkelsen). Initially, NBC claimed, Cho's packet was news, but "[o]nce you've seen it, its repetition is little more than pornography," one news executive claimed (ibid.) How convenient for them. How sad for us that "the fascination of the attack is primarily a fascination with the image" (Baudrillard 28). That these images are real adds another thrill: a layer of terror. Terrorism is a media event. Such acts become unforgivable and unforgettable once broadcast. But even that is illusory, for there is no good usage of the media in these cases. The media are an integral part of the event itself — and all of the Virginia Tech families' pleas to remember the dead instead of the murderer only remind us of the bizarre and vicious performances of the perpetrator. The media are a part of that terror and a part of the game. They unite the "white magic of the cinema and the black magic of terrorism" (Baudrillard 29-30), for, as Baudrillard says, the spectacle of terrorism imposes the terrorism of the spectacle (Baudrillard 30).

\section{Computer Game Violence}

Like flies in ointment, we are stuck in this conundrum. What is the distance between a Texas Chainsaw Massacre and a brutal sniper attack at the University of Texas at Austin campus in 1966? How far removed are digital bodies executed by religious extremists, blown apart for so-called fun in Mortal Kombat, Soldier of Fortune or Gears of War from the images of a first person shooter gunning for Virginia Tech students and staff? Computer and video games get singled out as the culprits of these homegrown attackers by right-wing critic Jack Thompson and others (Benedetti), even though study after study has shown that these games are dangerous only to the kind of people who already have difficulties distinguishing between the fictional and the real (Majendie). Kimveer Gill was, to be sure, a serious gamer as were the Columbine killers; Cho on the other hand was not. Not a single game was found on his computer in his dorm. But what is real and what is virtual in a digital age? Does violence not cross these boundaries precisely by the way it harnesses our fears and spreads terror, just as the suicide bomber's ultimate weapon is his body? In order to explore these connections, I will take a look at three different kinds of digital games and activities that purposely trouble the boundaries between real and fictional worlds.

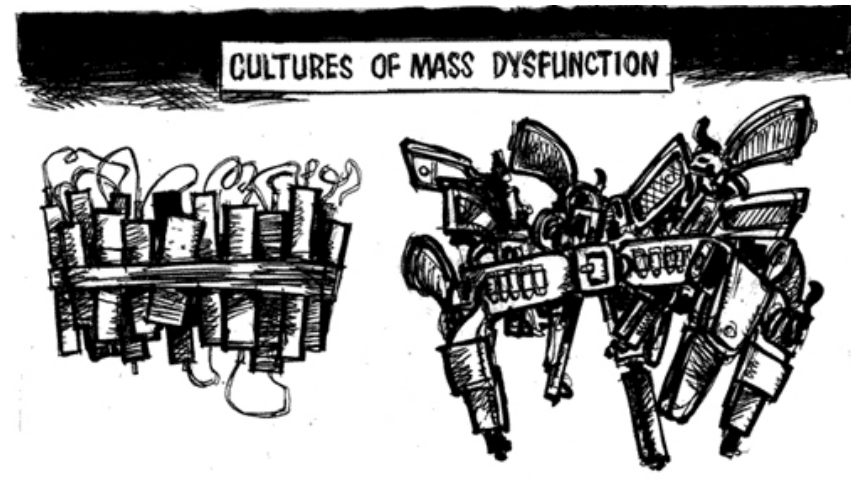

Braus:

Copyright Maurice Evans 2007. Used with permission. All rights reserved 


\section{| Pay-Per-View-Slaughter}

Early in 2005, a San Antonio rancher named John Lockwood set up a Website for hunters all over the world. With high-speed access and a fee, they could shoot deer, antelope, wild boar, and other game on his property using a Webcam and a remotely-controlled rifle. Lockwood planned to send them the head as a trophy. Before his venture got off the ground though, hunters and sportsman cried foul and Texas lawmakers moved in to declare his business illegal. It gave the animal no chance critics said, and there was no challenge for the hunter either (in fact, even during the initial demonstration the hunter only wounded the pig and Lockwood had to go and finish the job). Other states have since moved to outlaw the practice elsewhere, including it under provisions that make hunting big game in captivity illegal. Why all the hoopla? Hunting an animal with a high-powered weapon even in the flesh is hardly a fair contest in the first place. Arkansas State Senator Ruth Whitaker summed it up like this:

“The animal has no chance... There's no challenge for you-except knowing how to use a computer and push a button. You never left your tufted sofa. What's sportsmanlike about that?" So far a couple dozen states have blocked the practice, which the Humane Society calls "pay-per-view slaughter" (Associated Press).

Digital bodies litter the Internet. Virtual killing is a major industry. I found dozens of so-called games online in which one can torture or kill or humiliate Osama Bin Laden when I was researching this essay. Clearly this exceeds acceptable ethical boundaries. Other spaces online have no such plain demarcations.

\section{Terrorism in Second Life}

Second Life is not a game. " $[$ t does not have points, scores, winners or losers, levels, an end-strategy, or most of the other characteristics of games" (Wikipedia). What is does have is the first online economy, 5 million registered accounts (as of March 2007, Wikipedia) and the promise of a social new world with user-generated content that you can shape to meet your imaginative dreams. Based on Neal Stephenson's metaverse from the novel Snow Crash, Second Life is a virtual world software created by the company Linden Labs that has become something of an addiction for its most fervent users: it is a gathering space for residents with unique avatars or cartoon-like online personas to meet, converse, socialize, form alliances, trade and do business. Since residents control their own copyright on SL creations, own land and make money (in Linden dollars) within the world, there has been a strong movement to establish civil rights and freedoms. The Democratic presidential hopeful John Edwards was the first politician to set up shop there, an occurrence that is now commonplace. Multinational corporations, including Reebok and American Apparel, have also opened stores within SL.

When the first multinationals arrived, and Linden Labs altered some of the basic programming within the world to accommodate them, a handful of residents became alarmed about their in-world future if they were to be subject to the whims of the parent corporation. As a result, the Second Life Liberation Army (SLLA) was formed in April 2006 with a primary goal of universal suffrage. Comprised of a very small number of people (probably less than a dozen members), the SLLA conducts military operations to win rights for their virtual selves. (See images of so-called acts of terrorism in Second Life here). Their first attack was against the clothing store, American Apparel. They shot 'white balls', a visual effect, which obscured areas of the screen temporarily, and interfered with people's ability to see merchandise and to shop. Sometimes these effects actually pushed customers out of the store. This led to the SLLA being dubbed 'terrorists' by the outer world media when they learned of the events and the same media lighted on the phenomenon with a near-hysterical fervor. "An article published by Agence FrancePresse even claimed that 'virtual-world banes now mirror the havoc of the real one, as terrorists have launched a bombing campaign in Second Life" (McCarthy). This is a grievous misrepresentation of these events. Even when SLLA detonated so-called atomic bombs at Reebok and American Apparel's virtual stores, there was no damage committed. These attacks are simply visual pyrotechnics. "Some can temporarily freeze avatars, and [at their worst some] graphics-heavy attacks can crash residents' computers or Linden Lab’s servers” (McCarthy).

In-world since the media hype happened, the SLLA themselves have been subject to attacks called 'griefings' (griefers are people who annoy other people in cyberspace) including having their headquarters painted with Nazi symbols and being bombarded by Super Marios. In-worlders take the issue of avatar rights seriously, especially since 
Homeland Security has started a Second Life experiment. Griefings can take the form of a blitz of exploding pink pigs or an alien invasion. One anonymous griefer draped the American Apparel store with large pink penises, and in February of this year political protest took up real world issues as a group wearing Bush '08 badges attacked the John Edwards campaign office, blotting it with images of dinosaurs, obscenities and an image of Edwards sporting blackface (McCarthy).

\section{Hacktivism}

Political protest and the Internet have gone hand-in-hand for a long time. The first hacktivist, computer engineer Carmin Karasic, started out using similar methods. She uses the Internet to implement a strategy called hacktivism. The term was first coined in 1998 to describe an emerging hybrid form that unites the best attributes of peaceful social protest-activism — and tech-savvy online civil disobedience-hackerism. It should not be confused with its adolescent and illegal cousins, cracktivism—code cracking, vandalism, data blockades and the loss of digital data—or cyberterrorism — acts and agents of wanton destruction including worms and viruses.

Hacktivism as an artistic praxis was born in December 1997 when Carmin Karasic was so appalled by the events of the Acteal Massacre-45 Zapatistas were murdered at the hands of the Mexican government - that she set out to create a Web interface that would perform political protest as an aesthetic act. Her electronic civil disobedience engine (run by a collective called Electronic Disturbance Theatre) is named FloodNet; it is Karasic's brainchild in her war against injustice. Filling the browser page with the names of the dead, this activism tool "would access [for example] the page for Mexico's President Zedillo seeking bogus addresses", so the browser would return messages like "human_rights not found on this server" (Cassell). Unlike the attacks launched by cracktivists, no damage is done by this software agent, but political points are made.

When the Electronic Disturbance Theatre would alert its online activists to launch a protest they visit the group's website and click on FloodNet's icon. Given Karasic's politics, it is no accident that FloodNet must function as a community-based performance: "It was only actualized through thousands and thousands of participants," she remembers. "It was meaningless without the masses." Popular support transforms a random act of vandalism into a show of presence, she argues (qtd. in Cassell). Karasic sees her collectivity interface as something more closely akin to "conceptual art" than to cyberterrorism (Harmon). No one and no data are harmed in these 'attacks,' but websites are effectively shut down while the protest is being transmitted. While the Second Life Liberation Army has no such clear agenda or broad-based sanctioning as yet, other kinds of social protest are growing in-world. When the ultraright wing French nationalist group the Front National (who have been likened to the Klu Klux Klan) set up a SL headquarters for instance, the response from griefers was swift, adorning their site with Nazi insignia and endowing their leader's images with Hitler mustaches.

\section{| Super Columbine Massacre RPG!}

A considerably more controversial usage of computing technology is Danny Ledonne's Super Columbine Massacre RPG! (View the trailer). Styled as a video game set at Columbine High School, Ledonne's critical perspective requires us to step into the shoes of either Eric Harris or Dylan Klebold, in order to kill students, try to blow up the school, commit suicide, and ascend to hell where we must battle more demons. Shocking in its choice of subject matter and ruthlessly documentary in its material, Ledonne said that the events at Columbine were such a wake up call for him — for he feared that he had been heading down the same road himself — that he wanted to create a forum for the disaffected to discuss their feelings. Turning to art to find a medium to express his own anger at having been ferociously bullied, he has reclaimed his life and become a film and videogame maker.

He sees his free, downloadable game as a cautionary tale, educating damaged souls against the dangers of violent behaviour. Ledonne says in his artist's statement:

Eric Harris and Dylan Klebold, through their furious words and malevolent actions, can be understood as the canaries in the mine-foretelling of an "apocalypse soon" for those remaining to ponder their deeds. With 'Super Columbine Massacre RPG!', I present to you one of the darkest days in modern history and ask, “Are we willing to look in the mirror? 
You would expect a game like this that is so carefully documentary in nature, being stitched together from Harris and Klebold's journals, writings and videotapes, to be realistic. Instead Ledonne creates a cartoony, Nintendo-like game with cheesy music that takes the horror (but not the message) out of the events. Dead students (who are scored as types-Jock Boy, Preppy Girl, Sheltered Girl) turn into red squares, which do nothing to satisfy a taste for gore, blood or destruction. Instead stepping into the killers' shoes means that you must watch clips of movies that the pair found inspirational, retrace their steps, and listen to their bombastic, twisted philosophies on the world. Reducing their victims to types, despite Harris and Klebold complaining so bitterly about being pigeonholed by others, makes their hypocrisy palpable. Harris and Klebold did not just want to be the worst school killers ever. They wanted to be the worst mass murderers ever. If their bombs had worked the way they had planned, they had hoped to kill 600 people with the first blast alone. Similarly, in this game, every killing is a choice. In order to succeed in Hell and overcome the DOOM-derived demons there, you have to kill virtually every student in the school to acquire enough power to survive the so-called next level (Thompson).

\section{Cybercidal Games}

Denounced as a "monstrosity" by many and recently dropped from the edgy and previously unapologetic Slamdance "Guerrilla Gamemaker Competition" when sponsors threatened to pull out, Super Columbine Massacre is so misunderstood precisely because it uses the conventions of games - their visual and interactive language- to deal with these very real issues. The outraged opposition to this game demonstrates how little games are understood or taken seriously, which is one reason why they get blamed as a cause in so many of these violent attacks.

Ledonne would probably argue that games are a symptom of the disease of our spectacle-loving times, not the cause. It is easy to see the links, for instance, between Kevin Klerck's suicide as media event and Timothy Leary's celebration of death as dramatic events - styled, in their own minds, as both heroic and tragic theatre. Klerck was a notorious hacker (Kevin Early was his real name) who posted a suicide note to LiveJournal, continued to chat online for a time, and then put a shotgun to his own head and fired. Timothy Leary likewise hoped to Webcast his own death (instead his death was videotaped and will only be shown in a forthcoming documentary). They are not alone. Kimveer Gill posted pictures of himself posing with guns before he made the trek to Dawson College, and, cybercides - group suicide pacts made in chatrooms and carried out collectively in RL-are an escalating phenomenon, especially in Japan, which has the highest suicide rate in the world. (91 people in 34 separate events are known to have killed themselves in Japan in 2005; McCurry).

While splatter and twitch games are certainly not harmless, these bloody images are commonplace everywhere. They saturate our media, our advertising, and our entertainment on a daily basis. It is the action-based nature of games, however, that seems to make them favored targets for criticism and censorship. It was even assumed and misreported by newspapers after the Dawson College shooting that Gill must have played Super Columbine Massacre. While Gill was a big videogame player and included among his favourite games a number of the most violent ones ever created (including Grand Theft Auto, The Punisher, and Soldier of Fortune II; see an overview of the 10 Most Violent Games of all time here), one has to wonder if events might have played out differently for him if Gill had in fact ever tried on Super Columbine Massacre for size.

\section{Rage}

This virulent sickness that is so insidious in our society is rage. Rage is very different from anger, which arrives quickly in the moment in the presence of its cause and then is gone. (See the face of rage in a widely-reported road rage incident in Toronto's Kensington Market in 2006). Rage festers and burns slowly under the skin, often fed for years by feelings of indignation, entitlement and superiority, until it explodes with brief but catastrophic force. Rage is a product of abuse and is a disease of the dysfunctional ego.

The more we live connected in virtual worlds (in our minds or online) and disconnected from the real world the greater the potential mismatch between our egos and ourselves, between who we are and who we think we are. In March, "a report by American psychologists, [called] Inflated Egos over Time, suggested that social-network 
sites such as MySpace and YouTube were promoting damagingly high—and illusory-levels of self-esteem among teenagers" (Appleyard). The user-generated content revolution of Web 2.0, which includes blogging and other social network lifestyles, is in short fostering a new kind of egomania.

At their best blogs can uncover stories ignored by the mainstream media and expose deception or cover ups, but at their worst blogs are notorious for encouraging a particular kind of opinionated aggressor who will use any form of abuse to pump themselves up or to 'win' a point. Furthermore, since blogs mostly recycle material from one site to another, they produce a kind of shark-like feeding frenzy or emotional contagion that spreads from blog to blog. Oliver Kamm in The London Times thinks that bloggers are parasites that bully and poison debate (qtd in Appleyard):

In The Guardian, Jonathan Freedland pointed out that the abusive, vitriolic nature of many blogs had turned the blogosphere into a "claustrophobic environment, appealing chiefly to a certain kind of aggressive, point-scoring male-and utterly offputting to everyone else." (ibid.)

Freedland believes the defining feature in this phenomenon is the anonymity factor on the Web. People more frequently behave badly if no one knows who they are and there are no reprisals for doing so.

\section{Freedom to Abuse}

Early Internet culture was steeped in Libertarian values, and hackers lived by the motto that information wants to be free:

But simple libertarianism is a meaningless and easy creed. It takes little or no account of Isaiah Berlin's crucial distinction between "freedom to" and "freedom from", the latter requiring external controls of the individual. Or, as Kris Kristofferson put it, rather more resonantly, "Freedom's just another word for nothing left to lose." (Appleyard).

As the World Wide Web emerged and sprouted from that earlier infrastructure, it has incorporated all kinds of loopholes that make space for unrestricted harassing, abusive, spamming and hacking behaviour (Appleyard). And the potential for anonymity ensures that there are no reprisals. As the emotional bile builds at blog sites, it often evolves to dangerous levels allowing rage to become the reason for commenting, as blogger Kathy Sierra discovered in March 2007. The author of a popular blog, she is ranked among the top 50 technoratis on the Web. When, however, she deleted some offensive postings at her site, she was shocked at the violent responses she received (Stone). She has since been driven into police protected hiding on account of rape and death threats at her own and other blogs (Sierra).

In one of the last entries at her blog site, Sierra reflects on the phenomenon of emotional contagion. "Anger and resentment are the most contagious of emotions," according to an expert on road rage, she tells us. The anger and resentment that precedes road rage in particular is something that is easily passed from one driver to another, as one further provokes and imitates another that is near the breaking point (Sierra, "Angry/Negative"). Road rage in the flesh is accompanied by a sense of entitlement and superiority over other drivers. Like bloggers and other bullies at their worst, ragers "feel it is their duty to punish bad drivers and teach them 'lessons" (Kolton). Emotional contagion is the ultimate in mob mentality, and we all feel it to some extent in particular situations: when in the presence of someone who is angry, depressed or ill or happy, or of a team that is winning, we easily become infected by those extreme emotions.

\section{The Contagion Spreads}

This epidemic of deep psychopathological emotions seems to be spreading. Dave Grossman's book On Killing documents how profoundly difficult it has been to train people to kill each other in the history of warfare. Examining changing technologies in conditioning from World War II until the Vietnam War, Grossman's findings are terrifying. In World War II, even when faced with a direct attack by the enemy, no more than $15 \%$ of soldiers would fire their weapons. By the Vietnam War, 95\% of soldiers were firing (qtd in Millner 65). Now, as our entertainment applies 
many of these "stimulus discriminator" techniques to the population at large, Millner fears that we may be creating a generation of psychopaths (Millner 66).

While our children and our students may be the most susceptible to catching and transmitting these negative undercurrents, our society as a whole is experiencing this epidemic on a vast scale. Misogyny, homophobia and racism seem to be the most powerful catalysts for these outbursts of societal forms of road rage as witnessed recently in highly visible incidents with Mel Gibson, Michael Richards and Don Imus. In Imus's case, hip-hop was immediately deemed by many (just like computer games in the wake of campus shootings) to be the real villain responsible for the racist and sexist language that is gaining cultural currency in the mainstream. It is telling too that in computer games, as Sherry Millner notes, the possibility for empathizing with other characters is never an option (73).

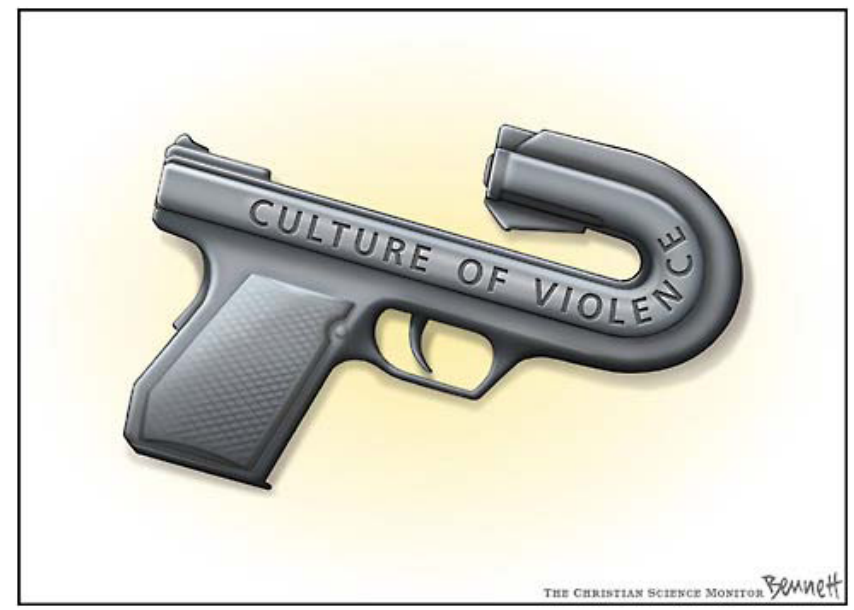

Copyright, Clay Bennett 2007. The Christian Science Monitor (www. csmonitor.com). All rights reserved.

Clearly boundaries are coming down and more raw, unrestrained, and disrespectful modes of expression are becoming commonplace, if still not officially acceptable. But, once more, this seems to be only a symptom of this sweeping disease that plagues us, with rage sending out shockwaves like tsunamis in a time when moral, cultural, economic and political values are undergoing violent change on a global scale. The more the United States engages in aggressive and bullying behavior-warranted or not-around the world, flexing its military muscles, the more we feel the backlash on the Home Front in the West (and not just in the United States). The Home Front used to be the purview of the civilian population in wartime. Now, we have lost sight of boundaries, sides and enemies. In an age of user-generated culture, we run the risk of living in a culture filled with homicidal/suicidal 'Armies of One,' each puffed up with a sense of his own self-importance, where everyone's concern is only for themselves.

\section{References}

----. BBC Photo Gallery. "In Pictures: Saddam in Custody." BBC Online. (15 Dec 2003).

----. "Prince's Weapon is a Camera-Gun." Modern Mechanix. (12 Dec 06). ----. "Second Life." Wikipedia. (22 Apr 07).

Alter, Lloyd. "Road Rage Live: Bikes, Beef Patties and Blogs.” Broadband. “Top 10 Most Violent Videogames.” DX Gaming. Treehugger.com (02 Feb 06).

Appleyard, Bryan. "The web is dead; long live the web." Carter, Bill. "NBC Defends Its Use of Material Sent By The Sunday Times Online. (22 Apr 07).

Associated Press. "Should Killing Be Merely a Mouse Click Away?” New York Times Online. (11 Mar 07).
Baudrillard, Jean. Spirit of Terrorism. Chris Turner, Trans. London and New York: Verso, 2002.

Benedetti, Winda. "Were Video Games Responsible For Massacre? Pundits rushed to judge industry, gamers in the wake of shooting." MSNBC News. (20 Apr 07). (02 Apr 07) Killer." New York Times Online. (20 April 07). ---. "Package Forced NBC To Make Tough Decisions." New York Times Online. (19 Apr 07). 
Cassel, David. "Hacktivism in the Cyberstreets." AlterNet. (30 May 2000).

Crecente, Brian. "Exclusive: Columbine Game Kicked From Competition." (05 Jan 07).

-----. “Gamer Was On Deadly Road.” RockyMountainNews. com. (24 May 06).

Cullen, Dave. "The Depressive and The Psychopath: At Last We Know Why The Columbine Killers Did it." Slate.com. (20 Apr 04).

Fox, Spider. “Top 10 Lists: Top 10 Most Violent Video Games Ever." Gamespot GameFacts. (2007)

Grossman, David. On Killing. New York: Little Brown and Company, 1995.

Gumbel, Andrew. "Stop Using All This Bad Language, Says Hip-Hop Pioneer." The Independent. (25 Apr 07).

Harmon, Amy. "'Hacktivists' of All Persuasions Take Their Struggle to the Web." New York Times Online. (31 Oct 1998).

Kaitlin. “Terrorists Attack Second Life.” NowPublic. (26 Feb 07).

Kolton, Tara. “Tackling Road Rage.” Doityourself.com.

Kuchera, Ben. "Super Columbine Massacre RPG pulled from Slamdance competition; the creator speaks with Opposable Thumbs." Opposable Thumbs. (09 Jan 07).

Leary, Timothy and R.U. Sirius. Design for Dying. New York: HarperCollins, 1998.

Ledonne, Danny. "Artist's Statement." Super Columbine Massacre RPG! 2005.

-----. Super Columbine Massacre RPG! 2005.

----. Super Columbine Massacre RPG! Trailer. Google Video. 2005.

Linden Labs. Second Life. 2003-07.

McCarthy, Caroline. "Griefing in 'Second Life"' CNETnews. com (05 Mar 07).

----. "In 'Second Life,' the ring of revolution?" CNETnews com. (05 Mar 07).

MacCloud, Scott. "Saddam's Hanging Reverberates Throughout the Middle East." TIME Online. (03 January 2007).

McCurry, Justin. "Nine Bodies Found As Japan Fails to Curb Internet Suicide Pacts." Guardian Unlimited. (11 March 2006).
McLuhan, Marshall. Understanding Media: The Extensions of Man. Toronto: Signet Books, 1964.

McLuhan, Marshall and Quentin Fiore. War and Peace in the Global Village. Corte Madera, CA: Gingko Press, 2001. [1968]

McLuhan, Marshall and Bruce Powers. The Global Village: Transformations in World Life and Media in the 21st Century. London: Oxford University Press, 1992.

Majendie, Paul. "Violent Video Games 'Exhilarating Escapism': Survey." Reuters. (18 Apr 07).

Mikkelsen, Randall. "U.S. Networks Limit Use of Va. Tech Gunman Video.” Yahoo! TV/Reuters. (19 Apr 07).

Millner, Sherry. "Wired for Violence." Digital Desires: Language, Identity and New Technologies. Cutting Edge: The Women's Research Group, Ed. New York and London: I.B. Tauris \& Co., 2000. 61-77.

Murray, Stuart. "McLuhan, Rhetoric, Philosophy." Unpublished talk delivered at Counterblast: McLuhan International Festival of the Future." University of Toronto (27 Sept 05).

----- "Thanatopolitics: On The Use of Death for Mobilizing Political Life." Polygraph: An International Journal of Politics and Culture. Vol. 18 (2006): 191-215.

Porter, Wayne. "Exclusive Interview with the Leader of the Second Life Liberation Army (SLLA)." (04 Dec 06).

Sanneh, Kelefa. "Don't Blame Hip-Hop." New York Times Online. (25 Apr 07).

Sierra, Kathy. "Angry/Negative People Can Be Bad For Your Brain." Blog: Passionate-Creating Passionate Users. (17 Apr 2007).

Stone, Brad. "A Call for Manners in the Nasty World of Blogs." New York Times Online. (09 Apr 07).

Strate, Lance. Blog Time Passing. (20 Apr 07).

Thompson, Clive. "I, Columbine Killer." Wired. (15 Jan 07).

Tripp, Stephanie. "VT-Y." 2007.

Turner, Jeremy O. "Terrorism is Temporary in Second Life." NowPublic. (26 Feb 07).

Walsh, Tony. "Politico Grabs Second Life Publicity." Clickable Culture. (31 Aug 06). 
